\title{
Pastoral caregiving as life science: Towards an existential hermeneutics of life within the interplay between pastoral healing (cura vitae) and spiritual wholeness
}

Author:
Daniël J. Louw ${ }^{1}$
Affiliation:
${ }^{1}$ Faculty of Theology,
North-West University,
South Africa
Corresponding author:
Daniël Louw,
djl@sun.ac.za
Dates:
Received: 31 Aug. 2016
Accepted: 28 Nov. 2016
Published: 12 June 2017
How to cite this article:
Louw, D.J., 2017, 'Pastoral
caregiving as life science:
Towards an existential
hermeneutics of life within
the interplay between
pastoral healing (cura vitae)
and spiritual wholeness', In
die Skriflig $51(1)$, a2183.
https://doi.org/10.4102/ids.
v51i1.2183
mobile device
to read online.
Copyright:
Read online:
(0) 2017. The Authors.
Licensee: AOSIS. This work
is licensed under the
Creative Commons
Attribution License.

Currently, the media is creating an illusion of youthful wellbeing: 'healthism'. But is life merely about physical health? What is meant by spiritual healing in pastoral caregiving? By means of the ontology of life and an existential analysis of the structure of being, a grid is developed in order to make a pastoral diagnosis regarding the interplay between different aspects and dimensions of the category life. It is argued that, seeing the bigger picture in a pastoral hermeneutics of life, contributes to spiritual healing (cura vitae). The basic assumption is that cura animarum should be designed in theory formation in pastoral caregiving as follows: faith care as life care. It is, in this respect, that the Christian spiritual categories of anastrephō, peripate $\bar{o}$ and hodos can be used in practical theological reflection to describe praxis in practical theology as fides quaerens vivendi [faith seeking lifestyles]. A spirituality of lifestyles points to habitus [human soulfulness] as new modes of 'walking with God' and 'living with God' (pneumatological praxis of God). Fides quaerens viviendi should be exemplified by a taxonomy of virtues.

\section{Introduction}

The notions of helping and healing have become burning issues in personal and social well-being. Healing and well-being within the parameters of a new focus on the sustainability of life are becoming factors in a global society obsessed by 'healthism'.

The contemporary concern with health and healing has become a central cultural value. Magazines project images of youthfulness, bodies developed to the maximum, physical fitness, men's muscle tone and women's beauty as the ideals of the human striving for health. The social focus on health as a core cultural value is creating a new religiosity: 'healthism' (Hunt 2003). Hunt (2003) also mentions that:

This term suggests not only a near cultural obsession with health as a matter of being free of sickness, but has come to denote a positive and proactive attitude to health. This preoccupation is derived from a number of wide but overlapping social developments, namely, instrumental rationalism, consumerism, materialistic lifestyles, and the advance of medical science. Healthism represents a focus on optimum performance and efficiency in all aspects of life. (pp. 183-184)

Yuval Noah Harari, in his book Homo Deus: A Brief History of Tomorrow (2015:29-43), points out that human health has become a fundamental issue in all cultures over the globe. Due to the constant emphasis on the connection between health and the human body as well as the quest for personal happiness and the 'upgrading of the human body and mind' in all kind of sports and even in medicine, life has become a kind of biochemical and bodily pursuit of happiness (Harari 2015:41). Genetic engineering, regenerative medicine and nanotechnology foster optimistic prophecies on human health. With reference to Kurzweil and De Grey (in Harari 2015:41) '... anyone possessing a healthy body and a healthy bank account in 2050 will have a serious shot at immortality by cheating death a decade at a time'. Harari (2015:43) thus concurs: 'The upgrading of humans into gods may follow any of three paths: biological engineering, cyborg engineering and the engineering of non-organic beings.'

Magazines on health issues are constantly projecting images of health that creates the illusion of hegemonic well-being. For example, the international magazine, Men's Health, projects instant and quick masculinity as something you achieve through hard exercise, diet, the development of 
brain power, going to the gym and capital investment. Health is then closely connected to human sexuality: 'Give her the body you've always wanted' (Men's Health 1999); 'Killer ABS, Kinky sex, Less fat, Bigger muscles, Extra energy, Instant cures, Smarter style' (Men's Health 2006). This magazine is read not only in Western countries, but in the east as well as in most countries in Africa.

A good indicator of the impact of communication technology and the mass media on being male or female is the concept of hegemonic masculinity ${ }^{1}$ : the athletic male body as a mark of power and moral superiority. It has become a dominant, global idol in Western thought: the white, middle-class heterosexual (Dworkin \& Wachs 2004:508). Hegemonic masculinity in the sports scenario, the so called David Beckman idol, infiltrates also the vast rural areas of soccer fields in Africa. Cell phones and the media are spreading a hamburger culture (the McDonaldization of world culture) that impacted eating habits and health in Africa. Coca Cola, bonophones and Marlboro cigarettes have become basic human rights in many poor areas (Mosotos News 2010:8). Obesity is not merely a Western problem; Coca-Cola poses a far deadlier threat than terrorism and al-Qaeda - even in developing countries (Harari 2015:18-20).

Health has become a lifestyle problem. What you eat determines who you are. Health has exceeded the parameters of the human body. It has become an identity problem linked to ideas that determine habits of everyday living. One can thus argue that health, as a lifestyle problem, has become in essence a spiritual matter; lifestyles (vivendi) determines the cure and care of human souls (cura animarum).

\section{From merely 'soul' to 'life' in a spirituality of health and healing}

In the tradition of pastoral caregiving, the connection healing and salvation is paramount. In fact, the notion of cura animarum was used to describe and identify the unique field of pastoral caregiving within the parameters of Christian, spiritual healing. Cura animarum [Cure or care of human souls] is the classical formulation for pastoral work. The problems confronting humans are not limited to merely physical, economic and material issues. Because people are also spiritual beings, the cure that they seek must also enable them to deal meaningfully with those issues that affect their daily lives.

Socrates grasped this profound truth. As a result, he did not wish to be merely a philosopher; he wanted to be a healer of the 'soul' (iatros tés psuchés) (in Oden 1987:187). Thus, his interest was in the connection between soulfulness, reason and virtue (Stace 1960:148-149).

Throughout the ages, people have always had to cope with the unruly emotions of guilt, fear, conflict and despair.

1.According to T Carrigan (2004.153) the differentiation of masculinities is psychological, but also institutional and an aspect of collective practice. Hegemonic
masculinity entails imposing a particular definition on other kinds of masculinity masculinity entails imposing a particular definition on other kinds of masculinity (Carrigan 2004:154)
The existential focus on the interplay between life (purposefulness), despair or nausea and death or tragedy is paramount in the attempt to grasp the soulfulness of life and quest for meaning in the being qualities of 'human souls'. One can call this quest for meaning an indication of the fact that a sense of purposefulness is a vital component of the spiritual dimension in the ontology of life.

At a conference of clinicians, medical educators and chaplains for medical school courses on spirituality and health in 1999, the following clinical definition of spirituality had been agreed upon (Puchalski \& Ferrell 2010):

Spirituality is the aspect of humanity that refers to the way individuals seek and express meaning and purpose, and the way they experience their connectedness to the moment, to self, to nature and to the significant or sacred. (p. 25)

Although spirituality is a many facet and layered concept with different nuances in academic circles, Corinna Dahlgrün (2009) argues that spirituality is closely connected to a transrational dimension of life. The dimension of the ultimate shapes the lives of human beings in daily experiences. According to Dahlgrün (2009:118-119), one can say that spirituality has to do with a meta-dimension concerning constructive values and virtues as well as a profound sensitivity for the transcendent realm of life (the beyond and ultimate dimension of life). Spirituality plays a fundamental role in the shaping of impressions that supersede normal worldly experiences. ${ }^{2}$

People are more than just the sum total of their physical, psychological and social components. They are spiritual beings and, as such, they ask the most fundamental question: What is the meaning of life? (McNeill 1951:321). In a theology of caregiving this spiritual question regarding the ultimate and its connection to God-images becomes paramount. Thus, Oden (1987) comments:

The care of souls therefore means the care of the inner life of persons, the mending and nurturing of this personal center of affect and willing. God is the chief carer of souls. (p. 187)

According to the practical theologian Firet (1977), human activity is not the central focus of the pastoral act and healing. Rather, it is about a spiritual and praxis activity that represents God's salvific presence which comes to humans through the ministry of an intermediator by means of his Word (Firet 1977:25).

But how does one connect this activity of God (the praxis of God) to human activity (the praxis of caregiving and healing)? Does healing in caregiving include the 'whole of life'?

2. Unter Spiritualität wird stets etwas verstanden, das mit einem über- oder transrationaler Betrachten und gestalten des Lebens zu tun hat, der Begriff steht für eine Haltung, für ein Tun, für eine Lebensstil, die aus einem bestimmten, die Welt übersteigenden Sicht der Welt resultieren, aus einer Orientierung an dem "Einen" ubersteigenden Sicht der Welt resultieren, aus einer Orientierung an dem "Einen oder an einem "Letzten", wobei von vornherein ausgemacht ist, um was es sich dabei handelt' 'With spirituality is meant more or less something that supersede our rational reflection, but is still connected to the shaping of life. The concep represents an attitude, an action, a mode of living, resulting from a transcenden dimension of the world, from an orientation that emanates from a principle or factor that determines the essential (last) meaning of human orientation] (Dahlgrün 2009:121-122 [author's translation]). 
My basic proposition is that healing in a 'wholistic approach' to caregiving (faith care) also implies life care (Louw 2016:2530). That is especially the case in African spiritualties. 'African indigenous healing is deeply rooted in the physical, emotional and spiritual aspects of being and is inextricably linked to religion or belief systems' (Edwards \& Edwards in Mpofu, Peltzer \& Bujuwoye 2011:8).

The need for salvation is not merely an 'inner need'. Salvation implies also the need for meaningful modes of life (soulfulness). The latter will be called the need for an intimate space wherein one can discover God's grace and compassion as a living presence that changes the structures and quality of lifestyles (fides quaerens vivendi).

\section{Life and lifestyle (vivendi) within the framework of wisdom and Hebrew thinking}

The Greek notion of life, which is aloof and contemplative (theōrètikos), is foreign and strange to Hebrew thinking. The ideal of Israelites was a life of active involvement, a life expressed by hunger and thirst, desires and lusts. 'To the Israelites, as to the oriental in general, the sheer vitality, concreteness and diversity of life were a course of the utmost delight (1 Ki. 3:11; Prov. 3:16; Job2:4); life synonymous with health, well-being and success (Mal. 2:5; Prov. 2:19; Ps. 56:13; Eccl. 9:9)' (Link 1976:478).

In Jewish writings, the Hebrew hālak, corresponding with the Greek anastrephō, describes in a figurative way, life as a 'way', a mode of walking in the way of God (positive), or walking in $\sin$ (negative). In a figurative sense, the verb anastrepho denotes the meaning of human behaviour: to walk, to conduct oneself, to live in a particular way (Ebel 1978a:933).

The way of life can be called the praxis dimension in practical theological thinking. It is about a designation for a conduct of meaningful life within the parameters of wisdom thinking. In this regard peripateo is used in a figurative sense as a description of a qualitative approach to life; an indication that one should conduct one's way of life in the paths of justice indicated by God's commandments. Ebel (1978c) comments that:

It obtains an outstanding significance as a term for denoting way of life; the nature and the manner of the way of life make it clear as to what governs a man in his being and acting. (p. 944)

In the New Testament, anastreph $\overline{\boldsymbol{o}}$ describes a way of life as new communion in Christ; to turn away from a previous way of life to a new life of obedience, piety and holiness (2 Cor 1:2; $1 \mathrm{Pt} 1: 15,17 ; 3: 16)$. Christian conduct is determined by fellowship with God and translates 'knowledge into practice' (Ebel 1978a:934). Fellowship with God implies a very specific praxis, namely to walk with God within the trajectories of life. Lifestyle denotes a kind of hodos, a kind of life. In a figurative sense, hodos as lifestyle describes the way one has to follow in order to reach a goal. Ebel (1978b) argues that: ...hodos can acquire the meaning of the means and way of reaching or carrying out something, measures, procedure, the style and way in which one does something and in which one lives. (p. 935)

The Christian lifestyle denotes a praxis methodos wherein one has to make decisions between arete [virtues that describes a good life] and kakia [badness]. In order to comply with the criteria for a 'good life', one has to walk the way of God; a way that is determined by the saving activity of God (Ps 67:3) and explained in the commandments (Gn 18:19).

Life in theology is in essence theonomous. It means that Yahweh is the author of life (Jr 17:13; Ps 36:9). 'Yahweh formed man from the dust of the ground and breathed divine breath into the lifeless body so that he became a living being (nēpeš hayyâ)' (Link 1976:478). The implication is that the whole physical, emotional and intellectual life of a human being stems from God.

One can conclude and say that in Hebrew thinking, the religious dimension of life is intertwined with the existential mode of habitus, that is, how faith is embodied in the dynamics of everyday living. Vivendi, thus, describes a mode of living that, as a praxis methodos, embodies God in lifestyles and virtues that contributes to the sanctification of both the cosmic realm as well as the dynamics of human relationships. In the New Testament the walk with God is exhibited by the excellent, unique mode of agape. Translated into pneumatological language, fides quaerens vivendi refers to the charisma of the Holy Spirit: the fruit of the Spirit is love, joy, peace, patience, kindness, goodness, faithfulness, gentleness and self-control (G1 5:22-23).

In wisdom thinking, human rights, justice and dignity are important ingredients of soulfulness that is, the mode of being as an exemplification of God's grace in an ethos of cruciform love. Life, ethos and habitus can be viewed as variants of the praxis of the human soul ${ }^{3}$ in biblical thinking: the imperative of the law is in fact a spiritual imperative (the soulfulness of life). It is about a habitus that will lead to the sanctification of life (Lv 19:15 - judge your neighbour fairly; Lv 19:9 - leave grapes for the poor and the alien).

\section{Habitus in soul care}

Besides the Hebrew dimension of soul as a qualitative mode of living within the dynamics of relationships (to love God and fellow human beings), habitus is a most helpful term, because it describes a qualitative mode of being and a responsiveness to the demands of life that can contribute to change and healing (spiritual wholeness). It correlates with what Gabriel Marcel (1962) calls a kind of disponibilité - a capacity for remaining 'available' to situations as they arise (in Bakewell 2016:86). Soul could be rendered as a mode of being in this world (Sosein) (Heidegger 1963:14).

3.'Dieses ausgezeichnete Seiende, das ens, quod natum est convenire cum omni ente, ist die Seele (anima)' (Heidegger 1963:14). It means: this specific mode of being that refers to the essence of all being that determines the qualitative mode of existence. 
Edward Farley (1983:27) advocated for the understanding of practice in Practical Theology as habitus. Theologia practica, for him, is habitus: 'Practice meant that aspect of the habitus or wisdom in which the divine object sets requirements of obedience and life'. He points out that literature in the Middle Ages calls theology a 'habitus, a disposition, power, act of the soul itself'. In essence, knowledge is episteme that points to habitus and to the quality of our being functions.

In their book Siblings by Choice, Smith and Riedel-Pfaefflin (2004:52) argue that habitus in a systems approach indicates a system of durable and transposable dispositions. Habitus serves as a culturally encoded way of being in the world that enables humans to co-operate and cope with the unforeseen and ever-changing situations of life. Habitus represents our position within historical and cultural settings and serves as an indication of the quality of our position in place and space.

Habitus can be rendered as an appropriate understanding of the notion of 'soul' in biblical thinking. With reference to a pastoral anthropology, habitus is the translation of attitude as the exemplification of the intentionality of Christ (phronesis Phlp 2:5). Habitus is more or less the equivalent of nefésh as a qualitative principle for life. Soul therefore indicates the stance of a human being (being function) before God. It functions as an equivalent for attitude (phronēsis). ${ }^{4}$

When néfésh is translated as psuché, it signifies what is vital in a human being in the broader sense of the quality of life and human relationships. In combination with heart (kardia) and mind (nous), soul in the New Testament describes the seat of life or even life itself. It represents the person in the broadest sense and indicates the quality of life experiences (habitus). Soul therefore does not refer in the first place to a different anthropological category, but to a different mode of being (Harder 1978:684).

The interplay between habitus (respondeo ergo sum), life virtues and the realm of meaning and purposefulness can be called a practical realism within an existential anthropology. Such a practical realism refers to practical reason (wisdom) that does not exclude the spiritual realm of life. The emphasis is thus on a hermeneutics of life from the spiritual perspective of signifying and denoting meaning, a non-reflexive habituality of creativity and common-sense (wisdom) (Coole \& Frost 2010:34).

Life is a void space of unpredictable dynamic events that surpasses positivistic predestinations and causative teleology. On the other hand, life implies more than merely being victimised by futility or paralysed by absurdity. The existential dynamics of life is determined by the capacity to transcend limitation in light of new prospects: vision (French: visuel [to see 'more' beyond the factuality of observation]).

4The word for psyche (psuché) is derived from a root, which means breath or to bre the breathe. The Hebrew word for soul, nefesh (Gn $2: 7$ ) mins bre of life that makes a principle of life (Seidl 19g.751). Nefesh denotes a principle of life that makes body, whether human or beast, into a living being (for a further discussion on life as a qualitative and relational concept, see Louw 2004:12-19).

\section{Spirituality as vision (visuel) within the existential dynamics of life}

Often the term spirituality is used synonymously with religion and has a binding and stabilising impact on people's attitude towards illness and suffering. "The word "religion" comes from the Latin term religare from re - again and ligare - to bind. Thus, religions talk of spiritual experiences as the rebinding to God' (Puchalski \& Ferrell 2010:22).

Richard Schröder (2009:12-13), in his book on the question whether religion should be abolished (Abschaffung der Religion?), points out that a world without religion does not guarantee heaven on earth. Current paradigms regarding the significance of religion refer to the fact that religion in one way or another is a given phenomenon and intertwined with cultural and meaningful orientation (purposefulness) in life. Research in sociology of religion argues that the word religion stands for the dimension of norm-value and meaningorientation. ${ }^{5}$ However, without religion, human existence runs the danger of losing its poetic gaze into guilt, sin, evil, ethic responsibility towards the 'ground of being' and an ethos of eucharistic gratitude. The real danger lurks that we end up with the atheism of indifference (Atheismus der Gleichkültigkeit) (Schröder 2009:189).

'Spirituality is for many people a way of engaging with the purpose and meaning of human existence and provides a reliable perspective on their lived experience and an orientation to the world' (Cobb, Puchalski \& Rumbold 2012:vii). Thus, the conviction of Pellegrino (2012:vi) that healing of the psychosocial-biological is, in itself, insufficient to repair the existential disarray of the patient's life without recognition of the spiritual origins of that disarray. Besides the dimension of significance and purpose, 'spirituality can be understood as one's relationship to a transcendence that for some people might be God and for others might be different concepts of how they see themselves' (Puchalski \& Ferrell 2010:1-21).

Within the framework of a Christian spirituality, the basic question in fides quaerens vivendi, is the 'will of God' enfleshed in a different way or mode of life. Vivendi points to a quality of life within the trajectories of everyday happenstances; it is about the quality of lifestyles within 'existentialia' - the everyday structures of our being human in this world.

Vivendi has also to do with the question of how one perceives and interpret everyday life experiences. It includes a kind of vision and 'perspectivism'.

With perspectivism is meant the complexity and Gestalt of different views, convictions, philosophies of life and belief systems as linked to the relativity of personal context, cultural

5.'Das Wort steht dann für die Dimension von Norm- Wert- und Sinnorientierung. Nach diesem Religann fur die Dimension von Num won einer atheistischen Religion 'Nach dies 'T Religionsbegriff kann man sinnvol auch-, Won einer atheistischen Religion sprech ' [The concept of religion represents the dimension of norm, value and the quest for meaning. With reference to this understanding of the concept of religion it is possible to refer to religion as an aesthetic entity - aesthetics of religion (Schröder 2009:93 [author's translation]). 
diversity, religious commitment and framework of moral values. Perspectivism can be linked to the different modes of human orientation towards different happenstances in life and how they impact on human attitude (habitus). Perspectivism could thus be seen as a mode of being (the how of being). It is directly linked to the question of how one respond to the existential realities of life. It is also qualified by what the French calls visuel.

The French philosopher Georges Didi-Huberman makes a profound distinction between 'visuel' and 'visible' (Cottin 2012:143). 'Visible' is about what one sees, what is visible for the senses. The visible can easily become an idol. 'Visuel' is about probing into the Ultimate (Jenseits), it sees by means of images and makes the invisible meaningful and it is a mode of signifying life in terms of transcendent-images and symbols. The 'visuel' operates by means of the creativity and imagination of the human mind due to normative frameworks of meaning. This unique mode of 'seeing' differs from the phenomenological gaze of empirical observation. The spiritual gaze, in an aesthetic approach to life, can be called an 'iconic gaze' (Louw 2014) within the dynamics of existential realities.

The point is that spirituality, as a many layered concept, is intertwined with psycho-social experiences and philosophical views, and religious convictions. It is a dynamic concept and should be understood in terms of life as a process category. The implication is that life, in itself, is not complete and fixed. It does not develop according to a mechanistic view of life or in terms of a fixed cause-and-effect schema wherein the outcome is already predestined by a static substance and causative principle. Things happen, change and develop in terms of complex systems (Morin 2008; Nilson 2007) and often by means of unpredictability and paradox (Taleb 2010). Existential thinking thus operates in terms of the dynamics of paradoxes. Paradox thinking discovers the surprise and unpredictability in life events - the indeterminism of happenstances within the realm of often opposing existential realities.

Existential realities determine the realm and quality of spirituality. They infiltrate the significance of daily living and can cause, what Kierkegaard (1967) calls, dread as the 'sickness' or 'pathology' of the human soul. In this regard dreadful life experiences and tragedy operate like spiritual viruses that determine the health of a human being. They are causing a kind of existential threat that can 'kill' human beings in their quest for meaning, hope and dignity. Thus, the reason why Heidegger (1963:316) argues that when one makes the category 'life' an object of study (life science), one, inevitably, has to take the notion of death seriously. At the same time, life does have a meta-realm of inspiring virtues and values. Life refers to a 'superseding value'; it is directed by a definite sense of values and purpose (Wilson 1966:160).

Existential thinking with its emphasis on choices, responsibility, freedom and vision is designed to meet the daily challenges of life. What are these challenges and how do they contribute to an understanding of spiritual wholeness in pastoral caregiving?

\section{'Existential realities' and their impact on the human quest for meaning}

The following six existential realities (see below) and threats or viruses of our being human can be distracted from general existential thinking. They determine the quality of human life on a daily scale. They should be understood in terms of the interplay between psycho-social and spiritual needs, and the eventual link to spiritual sources for find meaning in life (cura vitae) (Louw 2008). In a diagnostic approach (the attempt to identify the factors that determine habitus and the quality of daily living), one should accept the existential fact that suffering and human vulnerability are inevitable features of life. Life is demarcated by the existential realities of anxiety, guilt or shame ${ }^{6}$, despair, loneliness, anger and greed. Basic human needs (unconditional love, forgiveness and reconciliation, hope, sense of belongingness, experience of fulfilment or happiness and a sustainable livelihood) feature within and are shaped by these existential realities. In order to understand the bigger picture in the ontology of life, the description of existential realities with an exposition of existential-spiritualties and how they are linked with the religious dimension in Christian wisdom thinking will be supplemented.

\section{Existential suffering (reality) and the threat of anxiety that is the fear of being rejected and isolated within the dynamics of human relationships}

The core issue in anxiety is the fear for loss - loss, either due to past events or a possible loss in future. Linked to this existential threat is a possible inappropriate response: dread and misery. Such an inappropriate response can be called a kind of spiritual pathology or illness that causes an extreme experience of anguish. Faced with the reality of death, the anguish leads to severe forms of distress. Within human relationships anguish and dread are often the consequence and result of destructive prejudice and suspicion. Human beings are often killed in their identity when prejudice leads to discrimination (judgemental selection on the basis of biased and skewed social forms of negative exclusion emanating in marginalised social isolation) and stigmatisation (inhumane labelling as negative devaluation and existential disqualification of unwanted qualities).

In this regard our basic spiritual need is intimacy: the need to be accepted unconditionally for who you are without the fear of rejection. Intimacy points to the need for human dignity, positive acknowledgement and a sense of connectivity and belongingness, that is a safe space and place that guarantees intimacy and unconditional love (Heimat, Geborgenheit) 6.See Frans van Raalten (1964) on the impact of shame on human behaviour. 
(Bollnow 1955). Healing on a spiritual level presupposes an approach of mercy, grace and unqualified love.

\section{Existential suffering (reality) and the threat of guilt and shame}

Guilt and shame are linked to either experiences of failure and transgression or an awareness of human sinfulness: one fails in light of norms, values, customs or established laws for prescribed human behaviour.

Guilt and feelings of guilt from our past have the potential to destroy identity and self-esteem in the present and future orientation. Guilt corresponds with an experience of being judged (Strijards 1997:51) and irresponsible behaviour. Due to conscience one can be torn apart and haunted by images of self-punishment and temptation. The German concept of Anfechtung describes this kind of inner torment, anguish, self-accusation and agony.

Here our basic existential need is to be set free and to be liberated from the past. The need for liberation, freedom or deliverance sets in. In order to deal with the past in a constructive way, it is paramount for human beings to disclose and to face the truth of one's existence. In cases of unjust treatment and an exposure to oppression, there is the need for emancipation in order to move from disorientation to a new and different orientation. In case of human mistakes and unavoidable failure, healing presupposes spiritual sources that can contribute to reconciliation and forgiveness.

\section{Existential suffering (reality) and the threat of despair, despondency and doubt}

Deprived from all forms of hope, the loss of future orientation leads to regression and eventually the downward spiral of despondency sets in. One is then deprived of any meaningful source to carry on with life (the courage to be). The existential reality is the bleak experience of hopelessness (non-hope).

To be exposed to meaninglessness and voidness can rob one of hope. Instead of excitement about life, life turns into a nightmare; one starts to resist life (nausea). Life becomes meaningless with often suicide (existential negation) as the only exit from this purposeless boredom.

Our basic existential need is anticipation in hope. The whole of our human identity latches onto a sense of meaningful, future orientation - thus, the need for creativity, imagination and vision.

\section{Existential suffering (reality) and the threat of helplessness and vulnerability}

It is in loneliness, that one becomes in a much intensified way aware of human transitoriness; life is but a fleeting moment.

People often become emotionally sick, because they remain helpless victims within the different networks and structures of life (cf. the HIV epidemic, the Zika virus, global terrorism, etc.). Sometimes one becomes so emotionally exhausted that the depleted self cannot cope anymore without support and assistance.

Our basic existential need is for a functional and available but also viable - support system. The point is that total independency is a lie. One cannot cope with life on your own. Isolation kills the human soul.

Spiritual healing in this regard means the discovery of a kind of connectivity and sense of belongingness (mutual fellowship). This is the time when somebody should step in on behalf of the vulnerable and, by means of intercession and prayer, act on behalf of the other in order to empower. Spiritual healing is about the discovery of a hospitable space and place and to be exposed to diaconal outreaches.

\section{Existential suffering (reality) and threat of disillusionment, frustration, anger and unfilled needs}

Behind many acts of aggression and anger, lurk experiences of disillusionment and disappointment due to unfulfilled needs and expectations that have not been met in a meaningful way.

Anger is an expression of frustration due to unfulfilled needs. Needs are shaped by many contextual issues such as poverty, unemployment, poor housing and living conditions, violence and crime. The extreme expression of anger is aggression and violent behaviour. It is often exposed in the abuse of power. Anger, when it is fuelled by ideology and irrational belief systems, is often the hidden background of destructive behaviour and can even lead to religious fanaticism.

Our basic existential need is life fulfilment - a fulfilment of life expectations. The experience that one's life is fulfilled, creates intense moments of joy, happiness and pleasure.

Spiritual healing, in this regard, is related to the removal of destructive factors that compromise human dignity, justice and human rights as represented by the norms, values and ethical framework (moral framework and fibre of a society).

\section{Existential suffering (reality) and the threat of greed and insatiable desires (boredom)}

For human beings it is difficult to set a limit to their needs and desires. If desires are fulfilled in a materialistic way, insatiability in a materialistic society of profit and moneymaking often leads to the suffering of boredom. It seems as if it is part and parcel of our nature never to be satisfied, to abuse and to exploit. Within a market driven economy and the global pressure on consumption, we are busy to exhaust all natural resources and to endanger life on this planet.

One can say that the whole of cosmos is exposed to a kind of cosmic yearning for modesty and healing in order to address ecological issues. There is an urgent need for the preservation and conservation of natural resources. 
Our basic need is indeed the promotion of human welfare and the creation of a worldwide philosophy for a sustainable livelihood in order to address global issues such as famine and poverty - thus, the importance of a spirituality of sustainable stewardship.

The following diagnostic model (see Figure 1) is a schematic summary of a comprehensive and existential understanding of spiritual healing and indicates what is meant by wholeness in cura vitae. The diagram depicts the existential issues that determine our human quest for meaning and the ultimate. It illustrates the dynamic interplay between threat, pathology, human needs for meaningful living and possible spiritual sources for healing. The argument is that despite the factor of paradox within the experience of these existential realities, the graphic depiction helps one to start 'seeing' the bigger picture of life. This kind of vision (visuel) creates an understanding and meaningful hermeneutics that contributes to what can be called an existential and spiritual healing of life.

Spiritual healing implies, inter alia, a kind of 'wholeness' that helps one to see the bigger picture of the existential dynamics of life. The following figure is designed to understand the interplay between the reality of the existential dynamics of everyday life and the spiritual realm of human needs and religious dimension of sources that contribute to wisdom thinking (sapientia) in Christian spirituality.

In order to design a kind of grid for a spiritual diagnosis and hermeneutics, one needs to imply networking and complexification thinking, that is, each part is immediately related and connected to every other aspect and dimension in a paradoxical way. Together the whole picture creates a meaning that is more than the sub-total of every part. This sort of complexity does not imply perfect harmony, but a rather paradoxical complexity that describes an existential hermeneutics of life. It is about a hermeneutics that include human suffering and unexpected events of tragedy and human misery.

In order to see the bigger picture (a kind of teleology of spiritual wholeness), each existential threat is connected to a possible mode of pathology, but simultaneously to basic human needs and possible spiritual sources (belief systems or convictions and philosophical views of life) for meaningful living. The presupposition is that an understanding of the interconnectedness between existential threat, existential need and the spiritual level of belief systems construe wholeness and instigate processes of spiritual healing.

With reference to the above-mentioned 'bigger picture' on spiritual wholeness, one can conclude that spiritual healing and the beautification of life (cura vitae) entails the following components:

- A hermeneutical understanding: Insight in how the different existential issues are interrelated creates some sort of illumination: one starts to 'see' the bigger picture. One starts to see how the existential realities of suffering are linked to existential needs. It helps one to understand the connections between suffering, spiritual needs and possible existential and spiritual pathology. The bigger

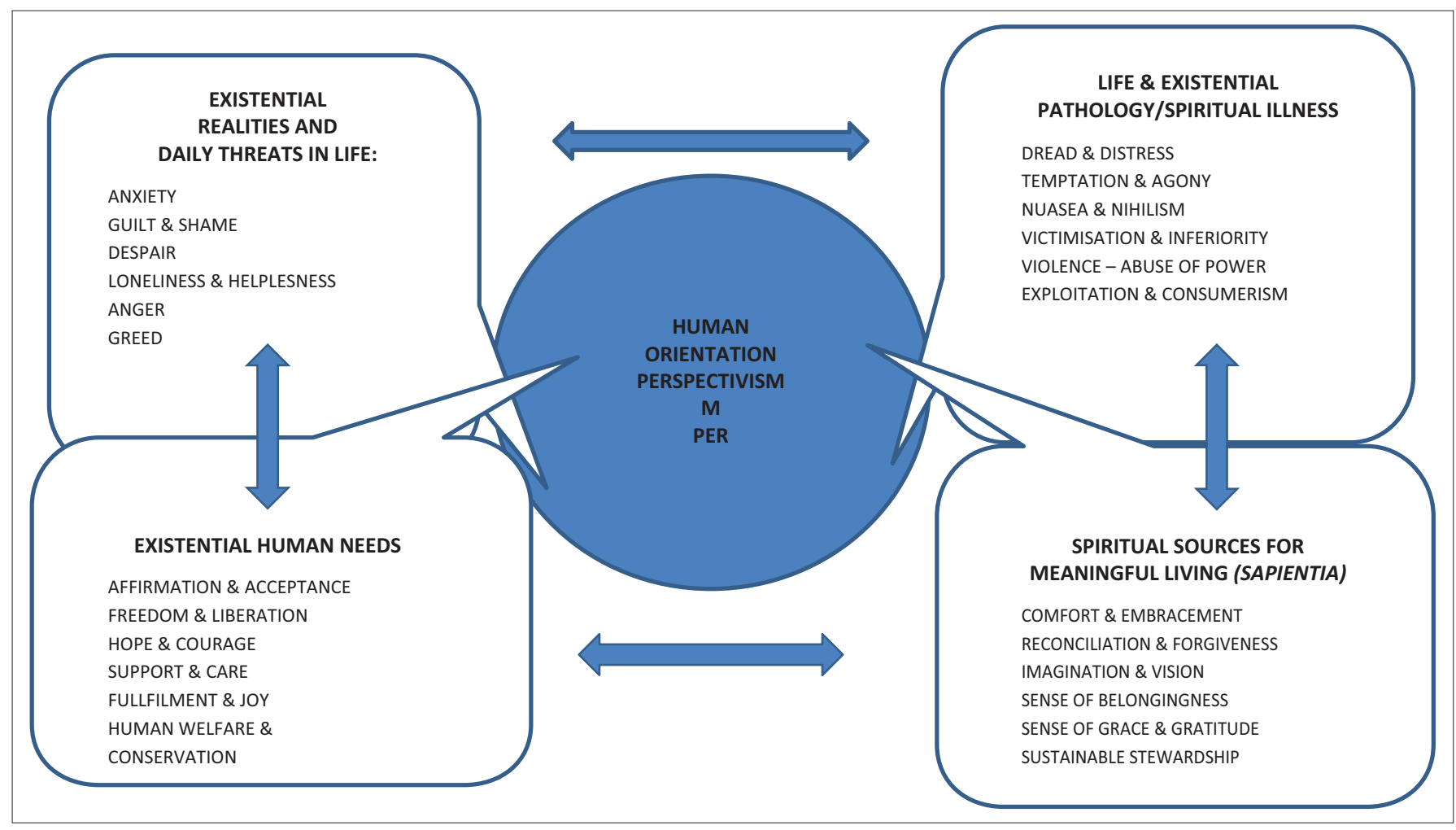

Source: Louw (2016)

FIGURE 1: On seeing the bigger picture of life. 
picture helps one to understand what is going on. Healing is not so much about a solution and answer, but more about attitude, vision, commitment, conviction, meaningful interpretation and realistic insight.

- Spiritual networking: Spirituality is not an abstract kind of idea regarding the meaning and purpose of life, but a new orientation in terms of different paradigmatic position and habitus. The spiritual process of existential networking transcends the artificial schism and dualism between life and faith. Spiritual networking is intrinsically about spiritual aesthetics and what can be called a taxonomy of spiritual values and virtues. ${ }^{7}$

- Reframing and change: Healing is about change. With change is meant to 'see' the same event from a different angle and perspective. Healing implies a kind of 'perspectivism' - a reorientation by which issues are renamed and re-purposed. Spiritual illness and pathology set in when one's vision becomes distorted and one sided. The links between the existential reality, the spiritual need and the spiritual source, help to discover possible alternatives. The anxiety is not so much about the loss and the fear for rejection, but about fixed ideas, rigid behaviour and a fear to change. However, the loss can also be seen as an opportunity for change and growth The emotional experience gives the message of dread, distress and meaninglessness; the bigger picture helps to create vision and hope.

- Imagination and vision (visuel): Seeing the bigger picture is already an existential form of hope. To discover the link between the existential reality of suffering and the knowledge of one's basic need for intimacy, freedom, hope, support, fulfilment and human welfare is to discover vision. One starts to anticipate something new and different in future. The spiritual dimension provides stability and continuity within the discontinuity. It fuels new orientation despite the disorientation.

The gist of the argument is that spiritual healing and wholeness occur when the above-mentioned existential threats can be linked to the following spiritual components:

- Intimacy: to be accepted unconditionally for whom you are without the fear of rejection: the need for love, the inclusiveness of kenotic love and the fellow suffering of divine passion;

- Hospitality: to create a space for human living beyond the social categories of discrimination and stigmatisation integrative and inclusive approach towards enemy and stranger and outsider;

- Deliverance: to be liberated from the transgressions of the past in order to be set free; the plea for freedom;

- Hope: to anticipate something new for change and transformation in order to set new goals for meaningful future orientation;

- Support: to have reliable structures that can help and assist one to cope with the demands of life;

7.As an expression of the praxis of God, praxis in practical theology is directly related to the response and habitus of human beings. Divine presence and human to the response and habitus of human beings. Divine presence and human
disposition constitutes a spiritual praxis of meaningful living (taxonomy of virtues disposition constitutes a spiritual praxis
and virtue ethics) (Sperry 2002:78-91).
- Fulfilment: to experience some sort of acknowledgement, satisfaction or happiness that kindles gratitude.

- Human welfare: to create a sustainable livelihood that cares for the preservation and conservation of the whole of cosmos.

To discover the link between the existential needs and the above-mentioned spiritual sources can be called the beautification of life. The hermeneutics of spiritual networking constitutes a rather spiritual aesthetics of healing. It also creates spaces and places for meaningful existence and the understanding of how a spiritual approach to ethics ${ }^{8}$ can enhance the quality of daily life experiences, choices ${ }^{9}$ and principles. $^{10}$

\section{Conclusion}

To 'see' the 'bigger picture' in life care is the first step towards a comprehensive understanding of healing in pastoral caregiving. An existential analysis is applied to give the bigger picture 'flesh' within the demands of daily life. Due to the already mentioned principle of habitus in a praxis of life care, the combination ethos and habitus is important. A praxis of faith care as life care should thus be guided and informed by the taxonomy of spiritual virtues. ${ }^{11}$ The taxonomy of virtues should be viewed as a practical theological expansion of the charisma, gifts and fruits of the Spirit. They describe a pneumatology of life and point to the praxis of faith seeking lifestyles: fides quaerens vivendi.

The taxonomy of lifestyles should be read together with the existential grid for the healing of life (on seeing the bigger picture of life). The following general lifestyles, engaging in the service of others, can be identified: purifying motivation, cultivating a true discernment or wisdom, living ethically, developing a peaceful mind, recognising the sacred in all or vision, finding meaning and purpose in life, and cultivating The taxonomy of lifestyles should be read together with the existential grid for the healing of life (on seeing the bigger

8.Crook (1995:5) argues that the essence of ethics is the making of value judgements. Its nature is to be prescriptive rather than descriptive. It is to recommend a way of acting, either for the achievement of desirable goals (teleological) or as a response to certain fundamental relationships (deontological). Theological ethics (Louw $2008: 175)$ can be described as a science that focuses on applying knowledge regarding the meaning and destiny of life issues - the quality of life, objectives and modes of living (lifestyles); the 'ought' of human behaviour - the evaluation of life in terms of normative criteria as they are related to basic commitments and belief systems.

9.It is one of the difficulties in Christian ethics that few problems are simple, clear-cut choices between right and wrong. Most problems people face are highly complex (cf. Crook 1995:9)

10.Ashley and O'Rourke (1989:175) see faith, love and hope as the criteria to classify and develop a set of ethical principles, specifically Christian, that can be applied to differentiate ethical and bioethical questions.

11.Virtue refers to the disposition or attitude that moves an individual to sustain practices, which enables the agent to accomplish moral good. It motivates people and brings about integrity. It represents enthusiasm for life (enthusiasm means literally 'God within us') and becomes a driving force in a sustainable hope. Virtues enable one to establish and nurture life-giving and healthy relationships. It safeguards human dignity and brings about a human space of moral soulfulness. Sound values are part of spiritual health. Vice points in the direction of spiritual pathology and indicates a kind of 'moral illness'.

Aristotle underlined the importance of virtues for purposeful actions. To this end he identified four basic virtues: prudence, justice, temperance and courage. In he identified four basic virtues. prudence, justice, temperance and courage. In philosophical schop function in this regard as soms, and victue philosophical school functioned in this regard as some sort of hospital and the first step towards getting better was recognising the vice in order to promote virtue in healing (Johnson 1999:34). The Hellenistic world thus found the ideal of culture (paideia) as the noble expression of virtue (arête) (Johnson 1999:36). 
picture of life). The following general lifestyles, engaging in the service of others, can be identified: purifying motivation, cultivating a true discernment or wisdom, living ethically, developing a peaceful mind, recognising the sacred in all or vision, finding meaning and purpose in life, and cultivating compassion and sensitivity. They are expressions of primary life virtues, namely charity, prudence, compassion, patience, trustworthiness or humility, fidelity or faithfulness, fortitude and courage, temperance, integrity or sincerity, embodiment and physical fitness (Louw 2008:281-284).

\section{Acknowledgements Competing interests}

The author declares that he has no financial or personal relationships which may have inappropriately influenced him in writing this article.

\section{References}

Ashley, B.M. \& O'Rourke, K.D., 1989, Health care ethics: A theological analysis, The Catholic Health Association, St Louis.

Bakewell, S., 2016, At the existentialist café: freedom, being, and apricot cocktails, Other Press, New York. https://doi.org/10.17104/9783406697654

Bollnow, O.F., 1955, Neue Geborgenheit: Das Problem der Überwindung des Exsistentialismus, Kohlhammer, Stuttgart.

Carrigan, T. 2004, 'Toward a new sociology of masculinity, in P.F. Murphy (ed.) Feminism and masculinities, pp. 151-165, University Press, Oxford.

Cobb, M., Puchalski, C.M. \& Rumbold, B., 2012, Preface: Oxford textbook of spirituality in healthcare, Oxford University Press, Oxford/New York. https://doi.org/10.1093/ med/9780199571390.001.0001

Coole, D. \& Frost, S., 2010, 'Introducing the new materialisms', in D. Coole \& S. Frost (eds.), New materialism: Ontology, agency and politics, pp. 1-46, Duke University Press, Durham/London. https://doi.org/10.1215/9780822392996-001

Cottin, J., 2012, 'Die Aufname der visuellen Dimension in der Biblische Hermeneutik am Beispiel von Paul Beauchamp and Paul Ricoer', in W. Gräb \& J. Cottin (Hrsg.), Religion - Ästhetik - Medien. Theologische, psychologische und ästhetische Reflexionen zur spirituellen Dimension der Kunst, Band 3, pp. 140-156, Peter Lang, Reflexionen zur spiritue
Frankfurt am Main.

Crook, R.H., 1995, An introduction to Christian ethics, Prentice-Hall, Englewood Cliffs.

Dahlgrün, C., 2009, Christliche Spiritualität: Formen und Traditionene der Suche nach Gott, De Gruyter, Berlin/New York.

Dworkin, S.L. \& Wachs, F.L., 2004, 'The morality/manhood paradox: Masculinity, sport and the media', in M.S. Kimmel \& M.A. Messner (eds.), Men's lives, pp. 507-521, Boston, Pearson.

Ebel, G., 1978a, 'Anastrephō' in C. Brown (ed.), The New International Dictionary of New Testament Theology, Vol. 3, pp. 933-935, The Paternoster Press, Exeter.

Ebel, G., 1978b, 'Hodos', in C. Brown (ed.), The New International Dictionary of New Testament Theology, Vol. 3, pp. 935-943, The Paternoster Press, Exeter.

Ebel, G., 1978c, 'Peripateō', in C. Brown (ed.), The New International Dictionary of New Testament Theology, vol. 3, pp. 943-945, The Paternoster Press, Exeter.

Farley, E. 1983, 'Theology and practice outside the clerical paradigm', in D. Browning (ed.), Practical theology, pp. 21-41, Harper \& Row, San Francisco.
Firet, J., 1977, Het agogisch moment in her pastoraal optreden, Kok, Kampen. Harari, Y.N., 2015, Homo Deus: A brief history of tomorrow, Harvill Secker, London. Harder, G., 1978, 'nous (reason)' in C. Brown (ed.), Dictionary of New Testament theology, vol. 3, pp. 122-130, Exeter, Paternoster Press.

Heidegger, M., 1963, Sein und Zeit, Max Niemeyer Verlag, Tübingen.

Hunt, S.J., 2003, Alternative religions: A sociological introduction, Ashgate, Hampshire.

Johnson, L.M., 1999, The writings of the New Testament: An interpretation, rev. edn., Fortress Press, Minneapolis.

Kierkegaard, S., 1967, The concept of dread, Princeton University Press, Princeton.

Link. H.-G., 1976, 'Life (bios)', in C. Brown (ed.), The New International Dictionary of New Testament theology, vol. 2, pp. 474-483, The Paternoster Press, Exeter.

Louw, D.J., 2004, Mechanics of the human soul, Sun Press, Stellenbosch.

Louw, D.J., 2008, Cura Vitae; IIIness and the healing of life, Lux Verbi, Wellington.

Louw, D.J., 2014, Icons: Imaging the unseen: On beauty and healing of life body and soul, Sun Press, Stellenbosch.

Louw, D.J., 2016, Wholeness in hope care: On nurturing the beauty of the human soul in spiritual healing, Lit Verlag, Berlin.

Marcel, G., 1962, Homo Viator: Introduction to metaphysics of hope, Harper \& Row, London/Chicago.

McNeill, J.T., 1951, A history of the cure of souls, Harper \& Row, New York.

Men's Health, 1999, 'The body you want', Men's Health, September.

Men's Health, 2012, 'Killer ABS, Kinky sex, Less fat, Bigger muscles, Extra energy, Instant cures, Smarter style', Men's Health, January-December.

Morin, E., 2008, On Complexity, Hampton Press, Inc, Cresskill.

Mosotos News, 2010, 'Africa achieves universal access: Cell phones finally available throughout all of Africa', Mosotos News, July 19, pp. 1-12.

Mpofu, E.K., Peltzer, O. \& Bojuwoye, O., 2011, 'Indigenous healing practices in Sub-Saharan Africa', in E. Mpofu (ed.), Counseling people of African ancestry, pp. 3-21, Cambridge University Press, New York. https://doi.org/10.1017/ CB09780511977350.004

Nilson, F., 2007, 'Towards a Dialectic Complexity Framework: Philosophical Reflections', in K.A. Richardson \& P. Cilliers (eds.), Explorations in Complexity Thinking: Pre-Proceedings of the 3rd International Workshop on Complexity and Philosophy, pp. 236-249, ISCE Publishing, Mansfield.

Oden, T.C., 1987, Pastoral theology: Essentials of ministry, Harper \& Row, San Francisco.

Pellegrino, E.D., 2012, 'Foreword', in M. Cobb, C.M. Puchlaski \& B. Rumbold (eds.), Oxford textbook of spirituality in healthcare, p. vi, Oxford University Press, Oxford/ New York.

Puchalski, C.M. \& Ferrell, B., 2010, Making health care whole: Integrating spirituality into patient care, Templeton Press, West Conshohocken.

Schröder, R., 2009, Abschaffung der Relgion? Wissenschaftlicher Fanatismus und die Folgen, Herder, Freiburg/Basel/Wien.

Seidl, H., 1999, 'Seele: Kirchen und Philosophie geschichtlich', in J. Muller (Hrsg.), Theologische Realenzyklopädie, Band 30, pp. 748-759, Walter de Gruyter, Berlin.

Smith, A.U. \& Riedel-Pfaefflin, U. 2004, Siblings by choice, Chalice Press, St Louis.

Sperry, L., 2002, Transforming self and community: Revisioning pastoral counselling and spirtiual direction, The Liturgical Press, Collegeville.

Stace, W.T., 1960, A critical history of Greek philosophy, Macmillan, London.

Strijards, H., 1997, Schuld en pastoraat: een poimenische studie over schuld als thema voor het pastorale gesprek, Kok, Kampen.

Taleb, N.N., 2010, The Black Swan: The impact of the highly improbable, Penguin Books, London.

Van Raalten, F., 1964, Schaamte en existentie: een onderzoek naar de plaats en de werking van de schaamte in de menselijke existentie in het bijzonder met betrekking tot het werk van Søren Kierkegaard, Callenbach, Nijkerk.

Wilson, C., 1966, Introduction to the New Existentialism, Hutchinson \& Co., London. 